\title{
ADOPTION OF BIOSECURITY FOR DISEASE PREVENTION AND CONTROL BY POULTRY FARMERS IN IMO STATE, NIGERIA
}

\author{
Tasie, C. M., Wilcox, G. I. and Kalio, A. E. \\ Department of Agricultural Science (Agricultural Economics and Extension Unit) \\ Faculty of Vocational and Technical Education \\ Ignatius Ajuru University of Education, Rumuolumeni, Port Harcourt, Rivers State, Nigeria \\ Corresponding Author Email: tasiechimezie@gmail.com 08038726818
}

\begin{abstract}
The study assessed the adoption of biosecurity for disease prevention and control by poultry farmers in Imo State. The objectives of study were to: ascertain the socio - economic characteristics of poultry farmers in Imo State; identify sources of informationon biosecurity measures adopted by poultry farmers for disease prevention and control in Imo State; ascertain biosecurity measures adopted by poultry farmers for disease prevention and control in Imo State; determine factors influencing adoption of biosecurity practices. A research survey of 60 owners and managers of poultry farms was used. A multi-stage sampling technique was used to select samples for the study and data were analysed using descriptive and inferential statistics (Logit regression). The study revealed that most of the poultry farmers in the study area were male and married and that these farmers were still intheiractiveandproductiveageand most of them were educated. Majority of the poultry farmers in the study area were micro and small scale farmers and have considerable experience in poultry production and are members of farmers' groups with profit motive as their farming enterprise objective. Majority of the poultry farmers had training in livestock management and most of the respondents did not receive any extension visit for the past two years up to the date of data collection and that the practice of biosecurity in the study area is high. Farmers association, veterinary officers, Internet and researchers are the significant sources of information on biosecurity to the poultry farmers in the study area. Age, cooperative membership, experience in poultry farming, training, farm size, education and access to credit significantly influenced the adoption of biosecurity practices in the study area. Any increase in the level of these variables would increase the level of adoption of biosecurity practices for disease prevention and control in the study area. Based on the findings of the this study, it is recommended that aggressive sensitization of the poultry farmers through seminars, workshops and conferences by relevant authorities on the advantages of adoption of biosecurity measures in their farms and encouraging fellow farmers to do so.
\end{abstract}

Key words: Adoption, biosecurity, disease, prevention, control, poultry farmers https://dx.doi.org/10.4314/jafs.v18i2.6 


\section{INTRODUCTION}

Livestock farming contributes to people's livelihoods through numerous channels: income, food, employment and transport, draft power, manure, savings, insurance and social status. Livestock keeping is an essential part of the Nigerian economy. About13million Nigerian households keep farm animals and the sector contributes 6 to 8 percent of the national GDP (Africa Sustainable Livestock (ASL) 2050, 2018). Food and Agriculture Organisation (FAO, 2010) posits that Nigeria has low animal protein intake with an average of $6 \mathrm{~g}$ per head per day while the world average is $34 \mathrm{~g}$ per head per day (FAO, 2010). FAO further asserts that animal protein constitutes only 3\%ofan average Nigerian meal, as against $12 \%$ recommended for healthy living.

TheNigerian poultry industry is made up of about180millionbirds and Nigeriahasthesecond largestchicken population inAfricaafterSouthAfrica(SAHEL, 2015); producing650 000 tonnesofeggsand300000tonnesofpoultry meat(Central Bank of Nigeria (CBN), 2019 and FAOSTAT,2017).The Central Bank of Nigeria (CBN, 2019) says the poultry sub-sector is the most commercialized of all Nigeria's agricultural sub-sectors with a current net worth of N1.6 trillion and the sub-sector contributes about $25 \%$ of agricultural gross domestic product (GDP) to the Nigerian economy. Poultry production is an important source of animal protein, income generation, employment, industrial raw materials, manure and financial security. Poultry include chicken, turkey, guinea fowl, pigeon, ostriches, quail, peafowl, duck and goose. Poultry refers to chickens kept for the purpose of meat and eggs. Poultry production outnumbers all other forms of livestock production in Nigeria and it thrives well in any part of thecountry (FAO, 2018 ).In spite of these important contributions of the poultry industry, Nigerian poultry sector faces high production costs, bio-risks, safety and biosecurity concerns due to lack of sanitary controls and technical constraints in production, processing and marketing. Diseases remain one of the major threats to boosting poultry production in Nigeria (Adewole,2012). The major diseases are the newcastle disease, avian influenza, avian pox, etc. (UsmanandDiarra,2008), with Newcastle disease being the most recognized by poultry farmers (Adeneand Oguntade,2006).Poultry farmers all over the worldface endemicdisease challenges that threaten poultry health, welfare and the profitability of the poultry enterprise. These diseases can have a substantial economic impact on individual enterprisesand onthe poultry industry as a whole (Wierup, 2012).The incessant outbreak of diseases in the poultry industry havemade the practice of biosecurityan essentialpractice to protect the poultry industry from bio-risks and threats fromany disease producingagents and the prevention and control of these diseases depends onthe adoption of biosecurity and best management practices.

Biosecurity has multiple meanings and is defined differently according to various disciplines. Koblentz (2010) defined biosecurity as a set of preventive measures designed to reduce the risk of transmission of infectious diseases in crops and livestock, quarantined pests, invasive alien

Journal of the Faculty of Agriculture and Veterinary Medicine, Imo State University Owerri website: www ajol.info; Attribution: Non-commercial CC BY-NC 
species, and living modified organisms. FAO (2008) explained biosecurity as management practicesto keep diseasesout of theflockthrough designing a combination of systems and practices to preven the adverseeffects ofdisease. It went further to say that biosecurity is a set of preventive measures designed to reduce the risk of disease transmission. These measures are a combination of systems and practices that are responses to the specific risks faced by producers. Biosecurity encompasses all policy and regulatory frameworks to manage risks associated with food and agriculture (including relevant environmental risks), fishes and forestry and constitute three sectors (namely food safety and security, plant life and health, and animal life and health). Poultry farm biosecurity ranges from simple, low cost measures such as putting locks on gates to the more costly measures such as using high - pressure water sprayers to clean cars and constructing shower blocks to secure visitors and workers as they enter the farm.Some biosecurity activities are management changes, which may below cost but require commitment from owners and farm workers to implements uccessfully. These include allocating a specific worker to a shed and not allowing staff to move from shed to shed. There are several factors that may influence the type of biosecurity measures adopted by broiler and layer poultryfarmers.

According to Mandal (2019), the main objective of biosecurity is to protect human health and to increase and protect agricultural produce through the prevention, control and management of biological risk factors. Biosecurity also aims to protect against acts of bioterrorism and to prevent adverse biosecurity events as well as offering advice on appropriate interventions and political and social changes that should be adopted by government regulatory agencies. Biosecurity is a pre - requisite for achieving the aims and objectives stated in the FAO strategic framework for promoting, developing and re-enforcing policy and regulatory frameworks for food, nutrition and environmental security (Paris, 2001). Biosecurity has direct relevance to food security and safety, nutrition security, the conservation of the environment (including bio diversity), and sustainability of agriculture.

Absence or neglect of biosecurity practices in poultry farms can give rise to unprecedented situations like high mortality rate, reduced profit and loss of investment. Therefore, based on the above background information, the broad objective of this study was to ascertain the biosecurity measuresadoptedby poultry farmers in Imo State,Nigeria.Specific objectives are to:ascertain the socioeconomic characteristics of poultry farmers in Imo State; identify sourcesofinformationon biosecurity measures adopted by poultry farmers Imo State; ascertainbiosecurity measuresadoptedby poultry farmers in Imo State; determine factors influencing adoption of biosecurity practices.

\section{METHODOLOGY}

The study was conducted in Imo state, Nigeria.The state is located in South eastern Nigeria. It is bordered by Anambra State to the North, Abia State to the East, Rivers State to the South, and Delta State and River Niger to the West. The state has three agricultural zones, namely; Okigwe, Orlu and Owerri zones and 27 Local Government Areas. The people in the State are 
predominantly farmers who engage in food and livestock production and marketing. Animals reared at both subsistence and commercial levels are poultry (broilers, layers), goats, sheep, pigs and fishes (Imo State Govt, 2020).

Descriptive survey research design was adopted. Multistage sampling technique was adopted for the study. In the first stage, 2 Local Government Areas (LGAs) with high number of poultry farmers were purposely selected from each of the agricultural zones, giving a total of 6 LGAs. In the second stage, 2 communities were randomly selected from each LGA, making a total of 12 communities. Thirdly, from each community, 5 poultry farmers were randomly selected from the sampling units in each community, giving a sample size of sixty (60) respondents.

Both primary and secondary data were used for the study. Primary data were collected with structured questionnaire. Secondary data were collected from published and unpublished materials. Both descriptive statistics and binary logistic regression model were used to achieve the stated objectives. The binary logistic regression model is implicitly stated as follows.

$\mathrm{Y}=\mathrm{Ln}(\mathrm{P} / 1-\mathrm{P})=$

$\mathrm{Y}=\mathrm{f}\left(\mathrm{X}_{1}, \mathrm{X}_{2}, \mathrm{X}_{3}, \mathrm{X}_{4}, \mathrm{X}_{5}, \mathrm{X}_{6}, \mathrm{X}_{7}, \mathrm{X}_{8}, \mathrm{X}_{9}, \mathrm{X}_{10}, \mathrm{X}_{11}\right)$

The functional form is expressed in explicit form as:

$\mathrm{Y}=\mathrm{b}_{0}+\mathrm{b}_{1} \mathrm{X}_{1}+\mathrm{b}_{2} \mathrm{X}_{2}+\mathrm{b}_{3} \mathrm{X}_{3}+\mathrm{b}_{4} \mathrm{X}_{4}+\mathrm{b}_{5} \mathrm{X}_{5}+\mathrm{b}_{6} \mathrm{X}_{6}+$

Where:

$\mathrm{Y}=$ Dependent binary variable (Adoption of biosecurity measures $=1$, Non - adoption $=0$ )

$\mathrm{X}_{1}=$ Age (years)

$\mathrm{X}_{2}=\operatorname{Sex}($ male $=1$, female $=0)$

$\mathrm{X}_{3}=$ Marital Status $($ married $=1$, single $=0$ )

$\mathrm{X}_{4}=$ Household size (number of persons in the household)

$\mathrm{X}_{5}=$ Cooperative membership $($ member $=1$, not a member $=0)$

$\mathrm{X}_{6}=$ Poultry experience (number of years in poultry production)

$\mathrm{X}_{7}=$ Access to training (number of times)

$\mathrm{X}_{8}=$ Flock size (number of birds)

$\mathrm{X}_{9}=$ Education (number of years in spent in school)

$\mathrm{X}_{10}=$ Extension contact (number of visit)

$\mathrm{X}_{11}=$ Credit access (savings $=1$, credit access $=0$ )

$\mathrm{b}_{0}=$ Constant

$b_{1}-b_{11}=$ Regression coefficients

$\mathrm{X}_{1}-\mathrm{X}_{11}=$ Independent variables

$\mathrm{Ln}=$ Logarithm

$\mathrm{P}=$ Probability of Adoption 


\section{RESULTS AND DISCUSSION}

\section{Socio-economic Characteristics of Poultry Farmers in Imo State}

Table 1 shows the socio-economic characteristics of the poultry farmers in Imo State. The Table showed that majority $(68.3 \%)$ of the poultry farmers are males. The reason for this can be attributed to the fact that poultry farming is labour intensive and so discourage women from engaging in it. This finding is in line with the studies of Alaladeet al. (2018) in Kwara State, Eze et al. (2017) in Enugu State, Ajewole and Akinwumi (2014) in Ekiti State, Bakare (2013) in Ose Local Government Area of Ondo State and Maikasuwa and Jabo (2011) in Sokoto State, Nigeria, who reported in their separate studies that poultry farming is dominated by the male folk.

Majority (50\%) of the respondents were between the ages of $41-50$ years and the mean age of respondents was 45 years. The respondents are mainly middle-aged farmers who are still active, productive and vibrant and are more likely to adopt innovations faster than others in the other age brackets. Poultry farming is labour intensive and requires younger farmers who can cope with the tedious and rigorous biosecurity practices including disease management. This finding is in consonant with Eze et al (2017) and Ibekwe et al. (2015).

The study revealed that majority $(80 \%)$ of the poultry farmers in the State are married. This means they have family responsibilities and should be committed to the biosecurity practices of their poultry enterprises so as not to reduce their farm income and profits. The table further showed that majority $(71.7 \%)$ of the respondents were well educated and are more likely to adopt innovations and biosecurity measures faster than others. High educational attainment is very essential, since practice of biosecurity and disease management requires some level of literacy and technical knowledge and also education enhances the farmers' productivity, accountability and profitability of the farm business. This finding is in agreement with Eze et al. (2017) and Ibekwe et al. (2015).

The result showed also, that the average household size is seven (7) persons. The average household size of the respondents is above national average of 5 persons in Nigeria (NBS, 2009). This large household size implies available labour for the poultry farm. The mean poultry farming experience of farmers in the study area is 17 years. This number is quite reasonable for any significant biosecurity improvement and achievement by the respondents in the study.

Survey results as presented in table 1 also shows that majority of the poultry farmers $(60 \%)$ in the study area belong to cooperative groups. Poultry farmers use the opportunity of being members of cooperative groups to interact and obtain information on how to improve the biosecurity of their farms. According to Ekong (2010), association with cooperative groups helps farmers to satisfy their innate need of solving their problems through collective efforts. Table1showalsothatabout $53.3 \%$ of the respondents have no access to farm credit; this may 
bedueto the fact that they are rarely considered as credit worthy because they have no collateral (Yisehak,2008). The farmers that have access to credit may be due their membership of cooperative groups.

Table 1 further showed that most (75\%) of the respondents have their enterprise objective as profit making (commercial). With profit motive as their enterprise objective, the poultry farmers would do everything possible to get information and practice biosecurity measures that would help them maximize their profit. This finding is agreement with Maduka, Igbokwe and Atsanda (2016). Also, majority (58\%) of the respondents keep less than 1000 birds in their farms and the mean flock size was 258 birds in the study area. This shows that poultry farmers in Imo State are micro and small-scale poultry farmers. This finding is in line with FAO (2008) and Agbola (2014).

The result also showed that most $(51.7 \%)$ of the respondents use deep litter system of poultry management. In the deep litter system, poultry birds have direct contact with their faecal matter. This implies high risk of infection and disease, which will result in high medication costs, increasing the overall cost of production Eze et al. (2017). In the battery cage system, the poultry droppings fall on the floor beneath the cages so the poultry birds have no contact with their faecal matter. This helps to reduce health risks and expenditure on drugs (Ayadole, 2016). Table 1 additionally, showed that majority $(71.7 \%)$ of the poultry farmers had training in Livestock management and /or veterinary science. Also majority $(90 \%)$ of the respondents did not receive any agricultural extension visit/services for the past two years up to the date of data collection.

\section{Sources of information on biosecurity measures adopted by poultry farmers Imo State}

Table 2 shows the sources of information on biosecurity measures adopted by poultry farmers in Imo State. The result showed that farmers association ranked $1^{\text {st }}(86.7 \%)$ as a source of information on biosecurity measures. Veterinary officers ranked $2^{\text {nd }}$. Internet and researchers ranked $3^{\text {rd }}$ and $4^{\text {th }}$ as sources of information on biosecurity. Othersourcesofinformation onpoultry biosecurity practices news media $\left(5^{\text {th }}\right)$, books/magazines $\left(6^{\text {th }}\right)$, seminar/workshops $\left(7^{\text {th }}\right)$, family and friends $\left(8^{\text {th }}\right)$, extension workers $\left(9^{\text {th }}\right)$, ministry of agriculture $\left(10^{\text {th }}\right)$ and feed and drug sellers $\left(11^{\text {th }}\right)$. Table 2 shows that poultry farmers in the study area have access to information on biosecurity practices from various sources. Correct and adequate information enhances a farmer's ability to make sound decision on matters regarding biosecurity in his farm (FAO, 2008). Maningaset al. (2005) and FAO (2008) opine that effective information, training, awareness and efficient delivery system of relevant information and technology services facilitates the poultry farmers' critical role in decision-making towards enhanced production, processing and marketing of poultry products.

\section{Biosecurity measures adopted by poultry farmers in Imo State}

The level of adoption of biosecurity measures by the poultry farmers in the study area is Journal of the Faculty of Agriculture and Veterinary Medicine, Imo State University Owerri website: www ajol.info; Attribution: Non-commercial CC BY-NC 
presented in Table 3. The table showed that all the respondents adopted the biosecurity measures listed above at different levels of adoption. Notwithstanding, only 14 biosecurity measures out of the 27 measures listed recorded $100 \%$ positive and significant response while the other 13 measures recorded various levels of response though positive and significant as presented in the table.

\section{Socio - economic factors influencing biosecurity practices in Imo State}

Table 4 shows the result of the binary logit regression analysis of the factors influencing the adoption of biosecurity practices. The result showed that age, cooperative membership, poultry experience, formal training, farm size, educational qualification and credit significantly influenced the adoption of biosecurity practices in the study area. Any increase in the level of these variables would increase the level of adoption of biosecurity practices in the study area. The $\mathrm{Chi}^{2}$ of $7.227(\mathrm{df}=11$ ) for model coefficient indicated socio - economic factors included in the model were significantly related to adoption of biosecurity measures in Imo State. The table

shows that the value of Pseudo $\mathrm{R}^{2}$ of the binary logit regression model was 0.625 which shows thatthe socio - economic variables includedinthemodel had very good predictive ability because $\mathrm{R}^{2}$ of 0.625 is close to 1 , indicating very good predictive ability and $1-\mathrm{R}^{2}$ error term.

\section{CONCLUSION}

Based on the result of the study, majority of thepoultryfarmers inthestudyareawere male and married and these farmers were still intheiractiveandproductiveageand were educated. From the findings, most of the poultry farmersinthe study area were micro and smallscalefarmers and have considerable experience in poultry production and are members of farmers groups with profit motive as their farming enterprise objective. Farmers associations, veterinary officers, Internet and researchers are the significant sources of information on biosecurity to the poultry farmers in the study area. Age, cooperative membership, experience in poultry farming, formal training, farm size, educational qualification and access to credit significantly influenced the adoption of biosecurity practices in the study area. Any increase in the level of these variables would increase the level of adoption of biosecurity practices in the study area.

\section{RECOMMENDATION}

Efforts should be made by government and relevant stakeholders to factor biosecurity measures into policiesand decisionsthat willencourage andmotivate smallholder poultry farmers toadoptingbiosecurity measures intheirfarms and agricultural extension services should be strengthened in the study area, seeing that it is non - existent to take charge of its primary responsibility of education, enlightenment and training of the poultry farmers on biosecurity innovations for disease prevention and control. 


\section{REFERENCES}

Adene, D. F. and Oguntade, A.E. (2006). The structure and importance of the commercial and village-based poultry industry in Nigeria. Poultry production systems, FAO, Rome, Italy. Pp: 1 - 102. https://www.fao.org/docs/eims/upload/21428/poultrysector.

Adewole, S.O. (2012). The efficacy of drugs in the treatment of coccidiosis in chicken inselected poultries. Acad. Res. Int., 2:20-24.

Africa Sustainable Livestock (ASL)2050 (2018). Livestockproduction systems spotlightNigeria. FAO, Rome, Italy.

Agbola, A. I. (2014). Agricultural Finance: A practical guide for lenders and entrepreneurs. Published by the Chartered Institute of Bankers of Nigeria Press Limited.

Ajewole, O.C. and Akinwumi, A. A. (2014). Awarenessand Practice of Biosecurity Measures in Small Scale Poultry Production in Ekiti State, Nigeria. Journal of Agriculture and Veterinary Science. $\quad V \quad$ (11): $24 \quad-\quad$ 29.www.iosrjournals.org. https://doi.org/10.12968/prma.2014.24.2.29

Alalade, O.A., Olorunfemi, O.D., Olaoye, I.J., Ladipo, T.O., and Yusuf, A. (2018). Assessment of Factors Influencing Biosecurity Measures Employed by Livestock Farmers in Selected LGAs of Kwara State, Nigeria. Journal of Science, Technology, Mathematics and Education (JOSTMED), 14 (2): 90 - 100.

Ayodele, J. (2016). Poultry (Chicken) farming: Advantage of using battery cages. Available at https://johnayodele.wordpress.com/2011/02/23/what-a-beginner-should-know-tosucceed-in-poultry-farming Accessed10/03/2020.

Central Bank of Nigeria (CBN), (2019). Nigeria's poultry industry now worth N1.6. https://www.thecable.ng/cbn-nigeria-poultry

Ekong, E.E. (2010). Introduction to Rural Sociology 3rd Ed. Uyo: Dove Educational Publishers

Eze, C.O., Chah, J.M., Uddin, I.O., Anugwa, I.J., and Igbokwe, E.M. (2017). Biosecurity Measures Employed by Poultry Farmers in Enugu State, Nigeria. Journal of Agricultural Extension. Vol.21(3): 89- 104. https://doi.org/10.4314/jae.v21i3.9

Food and Agriculture Organization, (2008). Biosecurity for highly pathogenic avian influenza: issues options. FAO, vialedelleterme di Caracalla, 00153 Rome, Italy.

Food and Agriculture Organization, (2010). Small holder poultry production livelihood food security and socio -cultural significance. FAO smallholder poultry production paper No 4, Rome.

Food and Agriculture Organization, (2018). Animal Genetic Resources, Nigeria (AnGR). Nigerian Livestock Resources Survey. www.Angr.org.ng 
FAOSTAT. (2017). Statistical data base of Food and Agricultural Organization of theUnited Nations. www.fao.org/faostat/en/\#data/QA.

Ibekwe U. C., Chikezie C., Ibeagwa, O. B., and Onyeoziri, M. N. (2015). Broilers Production among Small Scale Producers in Imo State, Nigeria: A Profit Function Analysis. International Journal of Research in Agriculture and Forestry. 2 (1): 40-45.

Imo State Government (2020). www.imostate.gov.ng

Koblentz, G. D. (2010). Biosecurity Reconsidered: Calibrating Biological Threats and Responses. $\quad$ International Security, $34 \quad$ (4): 96-132. https://doi.org/10.1162/isec.2010.34.4.96

Maduka, C. V., Igbokwe, I.O. and Atsanda, N. N. (2016). Appraisal of Chicken Production with Associated Biosecurity Practices in Commercial Poultry Farms Located in Jos, Nigeria. Scientifica. Pp 1 - 9. https://doi.org/10.1155/2016/1914692

Maikasuwa, M.A. and Jabo, M.S.M. (2011). Profitability of Backyard Poultry Farming in Sokoto Metropolis, Sokoto State, North-West, Nigeria. Nigerian Journal of Basic andApplied Science 19(1): 111-115ISSN 0794-5698. Available online at http://www.ajol.info/index.php/njbas/index. https://doi.org/10.4314/njbas.v19i1.69354

Mandal, A. (2019). What is biosecurity? Accessed online at www.news medical.net/biosecurity/what is biosecurity.

Maningas, R.V., Perez, V.O., Macaraig, A. J., Alesna, W. T. and Villagonzalo, J. (2005)."Electronic Information Dissemination through the Farmers' Information and Technology Services (FITS)/TechnoPinoyProgram. Bringing Information and Technology within the Reach of the Farmers." from http://jsai.or.jp/afita/afitaconf/2000/part08/p231.

National Bureau of Statistics (NBS), (2009). Social Statistics inNigeria.

SAHEL (2015). An Assessment of the Nigerian Poultry Sector.http://sahelcp.com/an-assessmentof-the-Nigerian-poultry-sector/. SAHEL11: 1-3.

Usman, B. A. and Diarra, S. S. (2008). Prevalent diseases and mortality in egg type layers. An overview international journal of poultry science $7: 304-310$. https://doi.org/10.3923/ijps.2008.304.310

Wierup, M. (2012). Principles and strategies for the prevention and control of infectious diseases in livestock and wildlife, In Ecology and Animal Health. L. Norrgren and J. Levengood, ed Bltic University Press. Uppsala, Sweden.

Yisehak, K. (2008). Gender Responsibility in Small Holder Mixed-Crop Livestock Production System of Jimma Zone, South West Ethiopia. Livestock Research for Rural Development, 20 (11).

Journal of the Faculty of Agriculture and Veterinary Medicine, Imo State University Owerri website: www ajol.info; Attribution: Non-commercial CC BY-NC 


\section{APPENDIX}

Table 1: Socio - economic characteristics of poultry farmers in Imo State

\begin{tabular}{|c|c|c|c|}
\hline Variables & Freq. & $\%$ & Mean \\
\hline \multicolumn{4}{|l|}{ Sex } \\
\hline Male & 41 & 68.3 & \\
\hline Female & 19 & 31.7 & \\
\hline Total & 60 & 100.0 & \\
\hline \multicolumn{4}{|l|}{ Age } \\
\hline $21-30$ & 5 & 8.3 & \\
\hline $31-40$ & 8 & 13.3 & 45 \\
\hline $41-50$ & 30 & 50.0 & \\
\hline $51-60$ & 13 & 21.7 & \\
\hline $61-70$ & 4 & 6.7 & \\
\hline Total & 60 & 100.0 & \\
\hline \multicolumn{4}{|l|}{ Marital Status } \\
\hline Single & 7 & 11.7 & \\
\hline Married & 48 & 80.0 & \\
\hline Widow(er) & 5 & 8.3 & \\
\hline Total & 60 & 100.0 & \\
\hline \multicolumn{4}{|c|}{ Level of Educational (Years) } \\
\hline Primary Education & 3 & 5 & \\
\hline Secondary Education & 14 & 23.3 & \\
\hline Tertiary Education & 43 & 71.7 & \\
\hline Total & 60 & 100.0 & \\
\hline \multicolumn{4}{|l|}{ Household Size } \\
\hline $1-5$ & 15 & 25.0 & \\
\hline $6-10$ & 40 & 66.7 & 7 \\
\hline $11-15$ & 5 & 8.3 & \\
\hline Total & 60 & 100.0 & \\
\hline \multicolumn{4}{|c|}{ Farming Experience (Years) } \\
\hline $1-10$ & 10 & 16.7 & \\
\hline $11-20$ & 32 & 25.0 & 17 \\
\hline $21-30$ & 13 & 43.3 & \\
\hline $31-40$ & 05 & 15.0 & \\
\hline Total & 60 & 100.0 & \\
\hline \multicolumn{4}{|c|}{ Cooperative Participation } \\
\hline Yes & 36 & 60.0 & \\
\hline No & 24 & 40.0 & \\
\hline Total & 60 & 100.0 & \\
\hline \multicolumn{4}{|l|}{ Access to Credit } \\
\hline Yes & 28 & 46.7 & \\
\hline No & 32 & 53.3 & \\
\hline Total & 60 & 100.0 & \\
\hline \multicolumn{4}{|l|}{ Enterprise Objective } \\
\hline Commercial & 45 & 75.0 & \\
\hline Family Consumption & 1 & 1.67 & \\
\hline Both & 14 & 23.3 & \\
\hline Total & 60 & 100 & \\
\hline
\end{tabular}

Journal of the Faculty of Agriculture and Veterinary Medicine, Imo State University Owerri website: www ajol.info; Attribution: Non-commercial CC BY-NC 


\begin{tabular}{lccc}
\hline Flock Size & 33 & 55.0 & \\
$\quad 1-200$ & 20 & 33.4 & 258 \\
$201-400$ & 5 & 8.3 & \\
$401-600$ & 2 & 3.3 & \\
$601-800$ & $\mathbf{6 0}$ & $\mathbf{1 0 0 . 0}$ & \\
Total & & 51.7 \\
Poultry Management System & 31 & 30.0 \\
Deep litter system & 18 & 18.3 \\
Battery cage system & 11 & $\mathbf{1 0 0 . 0}$ \\
Both & $\mathbf{6 0}$ & 71.7 \\
Total & & 28.3 \\
Training in poultry production & 43 & $\mathbf{1 0 0 . 0}$ \\
Yes & 17 & \\
No & $\mathbf{6 0}$ & 10.0 \\
Total & & 90.0 \\
Extension visits & 6 & $\mathbf{1 0 0 . 0}$ \\
Yes & 54 & \\
No & $\mathbf{6 0}$ & \\
Total & & \\
\hline
\end{tabular}

Source: Field Survey, 2019

Table 2: Sources of Information on biosecurity measures adopted

\begin{tabular}{lccc}
\hline Information Source & frequency & percentage & Rank \\
\hline Farmers Association & 52 & 86.7 & $1^{\text {st }}$ \\
Veterinary officers & 45 & 75.0 & $2^{\text {nd }}$ \\
Internet & 43 & 71.7 & $3^{\text {rd }}$ \\
Researchers & 40 & 66.7 & $4^{\text {th }}$ \\
News media (print and electronic) & 39 & 65.0 & $5^{\text {th }}$ \\
Books/ magazines & 38 & 63.3 & $6^{\text {th }}$ \\
Seminar/Workshop & 20 & 33.3 & $7^{\text {th }}$ \\
Family and Friends & 15 & 25.0 & $8^{\text {th }}$ \\
Extension workers & 8 & 13.3 & $9^{\text {th }}$ \\
Ministry of Agriculture & 5 & 8.3 & $10^{\text {th }}$ \\
Feed/Drug Sellers & 3 & 5.0 & $11^{\text {th }}$ \\
\hline
\end{tabular}

Source: Field Survey, 2019

Multiple responses recorded 
Volume 18, Number 2, October 2020, pp 85 - 97.

Table 3: Biosecurity measures adopted by poultry farmers in Imo State

\begin{tabular}{|c|c|c|}
\hline Biosecurity Measures & Frequency & Percentage \\
\hline 1. Limit non - essential human traffic on the farm & 57 & 95.0 \\
\hline 2. Restraining farm workers from visiting other farms & 55 & 91.7 \\
\hline 3. Keep other animals out of poultry building & 60 & 100.0 \\
\hline 4. Isolation of infected birds & 60 & 100.0 \\
\hline 5. Quarantine of new birds & 58 & 96.7 \\
\hline 6. Avoid mingling flock with local, wild/migratory birds & 55 & 91.7 \\
\hline 7. Examine flocks daily for disease symptoms & 60 & 100.0 \\
\hline 8. Keep a record of all farm visitors & 60 & 100.0 \\
\hline 9. Keeping birds of different ages separately & 59 & 98.3 \\
\hline 10.Selling crates along with eggs & 56 & 93.3 \\
\hline 11.No recycling of feed bags & 55 & 91.7 \\
\hline 12. Providing foot-dip with disinfectant & 60 & 100.0 \\
\hline 13. Separation of birds according to age & 60 & 100.0 \\
\hline 14.Proper washing and disinfection of feeding/water troughs & 60 & 100.0 \\
\hline 15. Ensure adequate ventilation for the birds & 60 & 100.0 \\
\hline 16.Constant cleaning of litter & 60 & 100.0 \\
\hline 17. Burying or burning of dead birds & 60 & 100.0 \\
\hline $\begin{array}{l}\text { 18. Keeping areas around poultry house/feed bins clean to keep } \\
\text { rodents away }\end{array}$ & 60 & 100.0 \\
\hline 19.Avoiding overcrowding & 57 & 95.0 \\
\hline 20.Ensure adequate floor spacing & 57 & 95.0 \\
\hline 21.Adequate feeding and drinking troughs & 60 & 100.0 \\
\hline 22.Fumigate poultry house and equipments before stocking & 58 & 96.7 \\
\hline 23.Separate transport for eggs and birds & 55 & 91.7 \\
\hline 24.Wash hands before and after handling poultry birds/products & 60 & 100.0 \\
\hline 25.Adequate light source for the birds & 56 & 93.3 \\
\hline 26.Regular vaccination of birds & 60 & 100.0 \\
\hline 27.Have only one entrance/exit & 50 & 83.3 \\
\hline
\end{tabular}

Source: Survey data, 2019

Journal of the Faculty of Agriculture and Veterinary Medicine, Imo State University Owerri website: www ajol.info; Attribution: Non-commercial CC BY-NC 
Journal of Agriculture and Food Sciences

Tasie, C. M., Wilcox, G. I. and Kalio, A. E. Volume 18, Number 2, October 2020, pp 85 - 97.

Table 4: Factors influencing biosecurity practices in Imo State

\begin{tabular}{lccc}
\hline Variables & Coefficient & Standard error & Z - value \\
\hline Constant & $60.67^{*}$ & 21.36 & 2.84 \\
Age & $0.68^{*}$ & 0.04 & 1.72 \\
Sex & -0.04 & 0.03 & -1.10 \\
Marital status & 0.17 & 0.16 & 1.09 \\
Household size & -0.35 & 0.04 & -0.98 \\
Cooperative membership & $0.04^{*}$ & 0.02 & 1.95 \\
Poultry experience & $0.03^{* *}$ & 0.13 & 2.30 \\
Formal training & $0.27^{* *}$ & 0.10 & 2.70 \\
Flock size & $0.34^{* *}$ & 0.15 & 2.27 \\
Educational qualification & $0.65^{*}$ & 0.37 & 1.80 \\
Extension contact & 0.21 & 0.24 & 0.87 \\
Credit access & $0.56^{*}$ & 0.31 & 1.78 \\
MC Fadden Pseudo R & 0.625 & & \\
Chi & & & \\
Log likelihood function & 7.227 & & \\
\hline
\end{tabular}

Source: Survey data, 2019

$* *$ Significant at $5 \%, *$ Significant at $10 \%$

Journal of the Faculty of Agriculture and Veterinary Medicine, Imo State University Owerri website: www ajol.info; Attribution: Non-commercial CC BY-NC 